\title{
Lost Identities: Youth Migration and Dispossession in Zimbabwe
}

\section{Peter Masvotore \\ ORCID iD: https://orcid.org/0000-0002-8398-1160}

\begin{abstract}
This article presents a historical analysis of the ways in which poor dispossessed Zimbabwean youth are coerced to migrate. It is argued that the dispossession and attendant migration left youth without knowledge of their identity that would have guided them into responsible citizenship in Zimbabwe. The article further underscores how economic hardships, neocolonial ideologies and facade opportunities become mapped onto adolescent bodies and spoil their dreams and aspirations. Using a desk research methodology this article draws from multidisciplinary sources to articulate how youth are unfortunately pushed to be resilient to (neo) colonial dispossession in Zimbabwe. In addition it demonstrates the shortcomings of state policies, some of which dehumanise, disempower and exclude youth. The article concludes by outlining key lessons that may be learnt from Zimbabwe. These lessons include the need to redress colonial dispossession of Zimbabwean land, and the need to not simplistically condemn the youth as aggressive, without factoring in the neo-colonially induced unbearable hardships that they face.
\end{abstract}

Keywords: lost identities, youth, migration, dispossession, Zimbabwe, colonial

\section{Introduction}

In as much as one's umbilical cord is buried in the ground to signify that his or her identity originates from the place of birth, Zimbabwean youth are colonially dispossessed and are forced to migrate from their place of origin due 


\section{Peter Masvotore}

to factors that are to be discussed later in the article. According to Masvotore (2019:309), 'dispossession and attendant migration left youth without knowledge of their past, present and future that would have guided them into responsible citizenship in Zimbabwe'. Considering this view, the article uses a post-colonial theory to argue that youth are also being ideologically migrated and displaced from their indigenous cultures, morals, ethics, patriotism, essences and identities to Euro-American cultures and hybrid identities marked by crises. The article demonstrates how economic hardships and facade opportunities map onto adolescent bodies and spoil their dreams and aspirations. Furthermore, the article also gives emphasis to the shortcomings of state policies, some of which dehumanise, disempower and exclude young people.

The article concludes by summarising the key lessons that may be learnt from Zimbabwe. These lessons include, among others, the need to redress colonial dispossession of African land. Also included is the need to not simplistically condemn African youth as violent, without factoring in the neocolonially induced excruciating hardships that they face and that predispose them to survivalist violence.

Even though the word 'youth' is defined to stand for people between the ages of 15 and 35 years of age, as preserved in the Constitution of Zimbabwe (Constitution of Zimbabwe Amendment (No.20) Act 2013:20; African Union Commission 2006:11), in this article the term is not only limited to age but extends to include lived experiences, regardless of age boundary. In addition, youth also refers to generational categories that are part of the struggle for influence and authority within every society (Ukeje \& Iwilade 2012:340, see also Catrine et al. 2006:11).

\section{Post-Colonial Theory}

As already indicated in the introduction, this article uses a post-colonial theory to assess how youth are forced to migrate and disposed of their identity. Tepeciklioglu (2012:2) indicates that the term 'post-colonial' may be assumed to be misleading since it refers to the period when the colonies of ex-European empires became independent sovereign states (see also Rukundwa \& van Aarde 2007:1171 - 1194). However, this definition would only mean that the colonial rule ceased by its all means. Given that the political independence is actually an illusion for these ex-colonies, colonialism continues in a neo- 
colonial mode and takes different forms. For these countries, the achievement of political independence did not solve the problems which were expected to be overcome by expelling colonial masters but instead, new forms of domination appeared (Ashcroft et al. 2003:2 - 7). New élites in these independent countries emerged and sustained the rule based on the exploitation of certain classes and colonialism reproduced itself under the name of neocolonialism.

In other words, the modern international system only has the formal appearance of decolonisation. Post-colonialism is a continuing process of resistance and reconstruction and post-colonial theory, thereby, involves discussion about the previously mentioned experience of various kinds of its expression, such as slavery, displacement, emigration, suppression, resistance, representation, difference, racial and cultural discrimination and gender; none of which is 'essentially' post-colonial, but together they form the complex fabric of the field. The term 'post-colonial' has come to stand for both the material effects of colonisation and the huge diversity of everyday and sometimes hidden responses to it (Ashcroft et al. 2003). This word, then, represents the continuing process of imperial suppressions and exchanges throughout this diverse range of societies, in their institutions and practices. Therefore, this article uses the post-colonial theory to demonstrate how this continuation of neo-colonialism has robbed the youth through of displacement, emigration, and discrimination and how they end up losing their identity after being displaced from their country of origin.

\section{Methodology}

This article is a historical analysis of the ways in which [poor] colonially dispossessed African youth were impelled to migrate. The article has used a desk research methodology. According to Creswell (2009) desk research includes secondary data or that which can be collected without fieldwork. Hakim (1982:1) defines secondary analysis as any further analysis of an existing dataset which presents interpretations, conclusions or knowledge additional to, or different from, those presented in the first report on the inquiry as a whole and its main results. In the context of this article the term is widened to include all sources of information that do not involve a field survey. This most certainly includes searching libraries and the internet. The article has relied a great deal on published books, journal articles and newspaper articles. 


\section{Peter Masvotore}

Desk research analysis is an empirical exercise that applies the same basic research principles as studies utilising primary data and has steps to be followed just as any other research method. As a result, this article utilised documentation from the original studies and information from published sources for a careful reflective examination and critical evaluation of the data in order to inform this study for a reliable conclusion.

\section{A Biblical and Historical Overview of Land as a Commodity that Gives Identity}

From a Biblical and a historical point of view, one can deduce that land plays a fundamental and crucial position in the history of humanity in general and in Zimbabwe in particular. A theological analysis of the Old Testament shows that land was the source of life, sustenance, hope, freedom and redemption (1 Kings 21:1 - 16; Numbers 26:53 - 54). This is also a true expression of the Zimbabwean youth in particular, who believe that land is a source of livelihood. For Zimbabwean youth, life is centred on their land which is inherited from their ancestors and it is part of their identity, where their umbilical cords are buried. Hence, they are the heirs and inheritors of their motherland (Herlihy et al. 2013). Furthermore, land for young people facilitates some form of dignity, integrity and source of prosperity in that it is in the land that resources for livelihood are found. Consequently, to be dispossessed of land is to be stripped of identity, selfhood and livelihood. Land is thus a crucial resource that provides meaning, sustenance, means for poverty eradication and a source of investment and wealth accumulation that is transferable from generation to generation among Zimbabweans (Bakare 1993). The spiritual realm of Africans, particularly Zimbabweans cannot be divorced from their land (Bourdillon 1976). Further to this, it is a religious space where the deceased and the living connect because of the umbilical cord buried in the ground, hence the saying mwana wevhu (son of the soil) (Herlihy et al. 2013).

The concept of mwana wevhu signifies a strong attachment to the land. It could be borrowed from the book of Job where humanity has always been reminded that he or she will return to the soil from which s/he originated (Job 1:21). What is surprising is that youth in Zimbabwe who are inheritors of this land are marginalised and forced to migrate to neighbouring countries like South Africa where they lose their identity in terms of social cohesion, morals 
and to a greater extent, a source of livelihood from their land. It is also a reality, as testified by Kanyenze et al. (2014: 275) and Masunungure (2014) that in Zimbabwe the formal sector employment was reduced by half, from a peak of 1.4 million employees in 1998 to an estimated 700000 employees in 2007. Thus, the observation stated above is supported by Nhemachena $(2017: 1)$ who argues that, Africa has already suffered not only enslavement and colonial dispossession but also recent harsh (neo) liberal reforms imposed by the International Monetary Fund (IMF) and World Bank. Furthermore, owners of industries across the world are adopting industrial technology that also dispossess youth of formal employment. In Zimbabwe, the Post and Telecommunications industry was left with no option but to retrench workers because of the introduction of technological devices such as cell phones and other Information and Communication Technologies (ICT) (Masunungure 2014). The continued loss of job opportunities, led Zimbabweans to migrate to countries like South Africa, Botswana, the United States of America (USA), the United Kingdom (UK), Germany and many others, in search of employment.

\section{Identity Loss, Migration and Dispossession of Zimbabwean Youth}

As Zimbabweans traverse from their places of origin, migrating to other countries in search of job opportunities, greener pastures as a result of harsh economic conditions, retrenchments, political instability, they end up adopting foreign cultures, ideologies and thereby losing their identity. Before engaging with the factors that lead to migration and dispossession, the term 'lost identity' has to be put into context. The word identity can be understood from two angles. It refers at the same time to social categories and to the sources of an individual's self-respect or dignity. In ordinary language, at least, one can use 'identity' to refer to personal characteristics or attributes that cannot naturally be expressed in terms of a social category, and in some contexts certain categories can be described as 'identities' even though no one sees them as central to their personal identity (Fearon 1999). Nonetheless, 'identity' is understood to reflect and evoke the idea that social categories are bound up with the bases of an individual's self-respect. Leary and Tangney (2012) define identities as the traits and characteristics, social relations, roles, and social group memberships that define who one is. Identities can be focused on the 


\section{Peter Masvotore}

past -what used to be true of one, the present - what is true of one now, or the future - the person one expects or wishes to become, the person one feels obligated to try to become, or the person one fears one may become. Identities are orienting, they provide a meaning-making lens and focus one's attention on some of the immediate context. As such, when one has lost identity it implies that one cannot define who s/he is in terms of traits, characteristics, social relations, roles and social group membership.

Having discussed what identity is and what lost identity implies it is therefore prudent to look at key factors driving youth dispossession. One of the key factors of youth dispossession and migration is colonialism that is evident in situations where Africans were forced off their fertile land and driven to infertile areas, called reserves in Zimbabwe. Chemwaita and Moyo (2014:43) defined reserves as 'areas that were demarcated for Africans to dwell in: they were not appropriate for human occupation.' It should be noted that the conditions in the reserves were extremely harsh; the soils were infertile and unproductive. These areas were disease-infected, received low rainfall and they were tsetse fly infested. Ranger (1967) says that Africans nicknamed these areas 'cemeteries or graveyards' because many people and their livestock died as a result of diseases and famine. One can deduce that Africans were forced to migrate from their land where their umbilical cords were preserved underground for their fortunes and were displaced to areas where they could not prosper.

Dispossession, during the colonial era, was followed up with forced labour which deprived African youth of opportunities to develop self-sufficiently. The colonial settlers demanded cheap labour on the colonial farms and mines. The target group for forced labour were youth who were deemed to be energetic enough to work in the farms and mines. Chemwaita and Moyo (2014:43) confirm that 'the district administrator forcibly rounded [up] men to work on the farms and mines; they were not well paid and were beaten up at [their] work places'. All this was in violation of human rights. In this regard, the colonialists never had respect for African marriages and families that were disregarded during the colonial forced labour regimes which separated husbands and wives. This is depicted as exercising freedom and human rights but it amounts to freedom and human rights designed to destroy human social institutions.

Neo-colonialism succeeds in depriving or dispossessing Zimbabwean youth of their God-given natural resources in the form of land and minerals such as gold and diamonds. Further to this, colonialism also displaced Africans 
through cultural domination. Ngugi wa Thiong'o (1993:32) underscores that, 'while there is need for cultures to interact and borrow from each other, this has to be on the basis of equality and mutual respect'. Adding to the above, Makombe (2014:90) affirms that 'centeredness is the basis of all knowledge and human development. A person must know where they stand in order to know in what direction they must proceed'. Makombe (2014) further noted that Western values have been presented as the ideal, at the expense of the local content. Furthermore Western/colonial education has destroyed African knowledge systems by celebrating Western heroes.

In Zimbabwe, the legendary white explorers like Cecil John Rhodes who are said to have discovered Africa, that was assumed to be a dark and chaotic continent, are venerated while African heroes like Chaminuka, Mbuya Nehanda, Mugabe and many others are denigrated. In this sense, while African scholars are fighting against the colonisation of their mind (Ngugi wa Thiong'o 1993), Euro-America is busy developing. Neo-colonial schools impart knowledge that looks down upon Africa and is thoroughly irrelevant to the African context. History indicates that missionaries also facilitated the process of dispossession and forced labour of poor African people. What is notable is that Nhemachena $(2016: 2)$ reminds us that 'much as colonial officials who presided over the colonial holocaust were proclaimed humanitarian and saints by Popes, empire and capitalism still retain the privilege to perpetrate planetary ultra-objective, systemic violence without being [held] accountable for it'. In other words, those that are considered the custodians of modern democracy and the rule of law are the same white people who formed minority apartheid governments that denied Africans, youth in particular, the right to vote and chart their own destiny. The Western epistemologies are questionable in Africa because the same were used to support the plundering of resources from Africa, through colonialism.

Colonial legislation that was oppressive served the interests of the minority white settlers, by oppressing and dehumanising Africans. Chemwaita and Moyo (2014:59) noted that colonisation followed some patterns that destroyed African independence through crafted pieces of legislation that were passed to justify the expropriation of African resources. Today the government is trying to address the colonial imbalances in land ownership. From land repossession to indigenisation laws and policies, there is evidence that the government of Zimbabwe is trying hard to redress the colonial criminality that resulted in dispossession and exploitation of Africans. 
Some scholarship opportunities are displayed before Zimbabwean youth to lure them into Eurocentric education systems that train them to 'excel in irrelevance' (Nyamnjoh 2012:130). This is worsened by the attraction of some of these scholarship opportunities that entice thousands of Zimbabweans to traverse outside its borders for academic 'development'. The risk is that some university campuses are infiltrated by secret intelligence agents that recruit and use foreign students to destabilise their own governments back in their home countries (Warikandwa et al. 2017). The actual quantum of Africa's 'brain drain', particularly in Zimbabwe, is difficult to fathom because there is no registration system that captures this kind of data. Moreover, some young people who leave Zimbabwe do so illegally so that their records are never captured.

Besides colonialism, there is also perpetual government failure in Zimbabwe in terms of policies that continue to create a society in perpetual crisis; worse for marginalised social categories like children, women and youth. Policies passed through legislation during and after colonialism also facilitated the loss of youth African identity, culture and possessions. This left some youth without a past or present - even their future is compromised.

Although black people have made advances in the control of mines, land and manufacturing sectors of the economy, the youth are still marginalised. The majority of Zimbabwean youth are not found at the centre of the economy, instead they are at the periphery of economic development in Zimbabwe and in Africa as a whole. Those in control of these economic sectors are the transnational corporations and some black political elites rather than ordinary youth (Nhemachena 2016).

In 1990, Zimbabwe's Economic Structural Adjustment Programme (ESAP) was introduced under the pretext of bringing about a modernised, competitive and export-led industrialisation process. However, the programme undermined the relative stability of Zimbabwe's economy. Panganayi (2014:184) describes IMF-led ESAP as a 'policy that involved among other things trade, currency de-regulation, devaluation of Zimbabwean dollar, lifting up of price controls, chopping of social spending and removing of consumer subsidies.' This liberalisation had a negative impact on Zimbabwean companies such as Triangle, Hippo Valley, Mkwasine, David Whitehead and others, that retrenched thousands of workers, (Panganayi 2014:185). Youth were left jobless and some became street vendors, even up to recent history.

Multitudes of young people were affected by ESAP, both directly and 
indirectly. Zimbabwe plunged into an accelerated spiral of economic and social decline and this led youth to be deprived of the means of survival, with some forced to migrate to neighbouring countries and overseas in search of employment. Even those in rural areas were not spared, instead the plight of the rural population worsened with ESAP. Muzondidya (2010) noted that as the agro-industrialisation sectors were de-industrialised, rural poverty increased as a result of ESAP's adverse effects on the agricultural output of the poor rural folks who could not survive above the poverty datum line.

Due to the unprecedented socio-economic and political challenges in Zimbabwe, migration has increasingly become a survival strategy. The country has gradually shifted from being a migrant-receiving country to being predominantly a transit and migrant-sending country. Zimbabwe has also been confronted by unique migration challenges, including, but not limited to, brain drain, irregular migration, and human trafficking and smuggling (International Organization for Migration (IOM) 2009). The education and health sectors typify the extent and effect of brain drain in the economic sectors. Emigration from Zimbabwe is far from being a new phenomenon. For instance, the migration of Zimbabweans to South Africa in order to work in the mining industry started as early as the beginning of the $20^{\text {th }}$ century (Zinyama 1990).

When looking at more recent emigration flows, two major phases can be distinguished. The first phase corresponds to the years following the country's independence in 1980. As described by Tevera and Crush (2003), between 1980 and 1984, 50000 to 60000 white people left the country because they could not adjust to the changed political situations and the net migration loss was over 10000 people per year. The second phase, from the 1990s to present, shows much more diverse and complex migration patterns than those in the first phase. Several significant characteristics can be identified with regard to emigration flows and, more generally, cross-border movements that have occurred since the 1990s.

First, there has been a progressive rise in emigration flows and crossborder movements; this rise has accelerated since 2000, as the national economic situation has dramatically deteriorated (Makina 2007; Muzondidya 2008; Kiwanuka \& Monson 2009; IOM 2009). Second, the vast majority of migration and cross-border movements occur within the Southern African region. Third, the main forms of migration and cross-border movements that have flourished since the 1990s are the following: irregular migration, informal cross-border trade, migration of highly skilled nationals, and survival 
migration of the poor and impoverished (Tevera \& Crush 2003). Although the characteristics of Zimbabwean migration - mainly irregular and circular impede the gathering of reliable estimates on migration flows and stocks, it is nevertheless useful to examine official data disseminated by Zimbabwe National Statistics Agency (ZIMSTAT). Such estimates are based on a definition of the notion of an emigrant that includes the following two categories: residents who, on departure, declare on border crossing cards that they are leaving for more than 12 months, and persons who registered themselves as visitors on arrival but stayed for more than 12 months in the country of destination. According to 2005 estimates, 11620 emigrants left the country, mainly to African countries (6256) and European countries (3758). The main destination country was the UK (3486), followed by Botswana (1524), South Africa (1502) and Mozambique (1390) (Central Statistical Office (CSO) 2005).

Furthermore, the introduction of policies, including Project Sunrise (Zuva rabuda, Ilanga seliphumile) and others negatively influenced Zimbabweans, most of whom are young people, in terms of economic empowerment. This project was meant to protect Zimbabweans against chaos in the financial or banking sectors and cash riots in the streets (Raftopoulos \& Mlambo 2009). Additionally, it was designed to alter and ameliorate people's socio-economic challenges (Gono 2009). It was initiated to increase liquidity by introducing bearer cheques. However, the Zuva Rabuda project negatively impacted Zimbabweans because even though the project was meant to protect people from financial chaos, the introduction of bearer cheques resulted in hyperinflation. This resulted in the rapid loss in value of the Zimbabwean currency and led to dollarization of economic transactions (Raftopoulos \& Mlambo 2009: 222). This policy led young people to migrate from Zimbabwe to other countries in search of employment and greener pastures. As if this was not enough, on 24 June 2019, the Reserve Bank of Zimbabwe abolished multiple currencies and made the Zimbabwean Dollar (ZWL) the sole currency with the Legal Tender Regulations Statutory Instrument 142 of 2019 (SI 142). Foreign currencies such as the British Pound, US Dollar, South African Rand, and Botswana Pula were no longer legal tender and the value of RTGS dollars were on par with the Zimbabwe Dollar. This has left many youth dispossessed, especially those who were trading in foreign currency in their small business enterprises such as flea markets, small scale miners and cross border traders (Herald 2019). 
Another policy code named 'Operation Murambatsvina' (Restore Order) was launched in June 2005 to ensure that sanity returned to urban areas and business centres in the country. All unauthorised vending sites and buildings were destroyed. Consequentially, some people were affected by this operation and relocated to rural areas while others were left homeless. For this reason, it is argued that this operation disempowered many people either through loss of accommodation, livelihoods or both (United Nations (UN) 2005). Most adversely affected by this operation were the youth who had started vending activities in cities and towns.

The impact of Operation Murambatsvina included among others, the destruction of the AIDS centre in Hatcliffe that served over 600 people (Maposa et al. 2010: 197). For most Zimbabweans, the HIV and AIDS repercussions of the forced removals were a setback as some of them were relocated to places where they could not access their medication (AntiRetroviral Therapy). The situation was further worsened by the fact that in the rural areas, the health services were under-resourced and the centres understaffed. Moyo (2000) viewed the clean-up as a response to the reassertion of state authority and reigning in of radical elements within the ZANU PF party, the regulation of the economy and crackdown on corruption and the restoration of functioning services to cities. On the contrary, Maposa et al. (2010:197) says, the Operation Murambatsvina can be viewed from a political angle where the MDC party argued that the operation was designed to destroy the party's urban base. They further argued that by relocating people to rural areas, their political support was weakened as those relocated to the rural areas would be under the sway of ruling party aligned Chiefs. Some of the youth who were affected by this operation resorted to cross borders into neighbouring countries such as South Africa, Mozambique, Zambia and Botswana in search of job opportunities where some entered into marriages of convenience. Some married foreigners in order to have resident permits in these foreign countries.

In addition to the above policies, an operation code-named 'Chikorokoza Chapera' was unleashed in November 2006 where the homes of thousands of informal miners were destroyed. The government accused the informal miners of fuelling inflation by selling gold on the parallel market (Utete 2003). After the displacement of these young informal miners, the government took over in places such as Chiadzwa where it is now in the public domain that 15 billion US Dollars went missing and never contributed to the national fiscus (Herald 28 April 2016; Newsday 16 March 2016; Daily News 


\section{Peter Masvotore}

1 January 2018). It can be deduced from these policies that they were crafted with a hidden agenda even though they may appear to be serving the people; they never benefited the majority of the people. Only the few political heavy weights benefited, and these policies continue to disenfranchise Zimbabwean youth. The above attempts by Zimbabwean government buttress NdlovuGatsheni's question, 'do Zimbabweans exist?' This is where he engages with the aspects of nationalism, including being identified with one's own nation and supports its interests especially to the detriment of the interests of other nations (2009:426).

\section{Conclusion}

The article has argued that the dispossession and attendant migration has left youth without knowledge of their identity that would have guided them into responsible citizenship in Zimbabwe. It further underscores and demonstrates how economic hardships, neo-colonial ideologies and facade opportunities map onto adolescent bodies and spoil their dreams and aspirations. This article also articulated how young people are unfortunately pushed to be resilient to (neo) colonial dispossession in Zimbabwe. In addition, it also demonstrates the shortcomings of state policies, some of which dehumanise, disempower and exclude young people.

There are key lessons to be learnt from this paper. In Zimbabwe particularly, young people migrate to other countries in search of job opportunities. They are often enthused by inaccurate information and unfounded high expectations. Every day, thousands of young people either willingly or unwillingly join the ranks of illegal migrants. A parallel industry of illicit travel agents, job brokers and middlemen has evolved to 'assist' these migrants, many of whom are also victims of human trafficking. For this reason, young women and girls who are impoverished and uneducated and who may be members of indigenous, ethnic minority, rural or refugee groups are most vulnerable to this form of exploitation.

In order to avoid dispossession and youth migration with its attendant risks and disadvantages, governments need to create viable employment alternatives for young people in their home countries. At a more fundamental level, action must be taken to address root causes such as dispossession, exploitation, poverty and contribute to narrowing the inequalities between rich and poor nations. Efforts are also required to ensure that young people are 
provided with sufficient education, training and skills development to gain the knowledge and confidence they need to become successful participants in their national labour markets.

Since land occupies the central and crucial position in the history of Africans, there is need to redress colonial dispossession of African land in order to create opportunities for young people to have a source of life, sustenance, hope, freedom, redemption and to take pride in their land as a source of their livelihood, passed down from one generation to another. For Africans, acquiring land for Africans is a form of dignity, integrity and source of prosperity. As such, to be dispossessed of this jewel resource is to be stripped of their selfhood.

\section{References}

African Union Commission 2006. African Youth Charter. Bangul: The Gambia. https://www.un.org/en/africa/osaa/pdf/au/african youth charter 2006.p $\underline{\mathrm{df}}$

Ashcroft, B., G. Gareth \& T. Hellen 2003. The Post Colonial Studies Reader. USA and Canada: Routledge.

Bakare, S. 1993. My Right to Land in the Bible and in Zimbabwe: A Theology of Land for Zimbabwe. Harare: Zimbabwe Council of Churches.

Bourdillon, M. 1976. Shona People. Gweru: Mambo Press.

Catrine, C., M. Utas \& H. Vigh 2006. Navigating Youth, Generating Adulthood. In Catrine, C., M. Utas \& H. Vigh (eds.): Navigating Youth, Generating Adulthood: Social Becoming in an African Context. Uppsala: Nordic Africa Institute.

Chemwaita, T. \& T. Moyo 2014. Colonial Rule up to 1923. In Moyo, T., T. Chemwaita, T. Murairwa \& M. Panganayi (eds.): National and Strategic Studies Volume One: Diploma in Education Open and Distance Learning. Harare: UZ Department of Teacher Education.

Creswell, J. W. 2009. Research Design: Qualitative, Quantitative, and Mixed Methods Approaches. $3^{\text {rd }}$ Edition. Thousand Oaks, CA: Sage.

Central Statistical Office (CSO) 2005. Annual Migration and Tourism Statistics Report. Daily News, 1 January 2018.

https://www.dailynews.co.zw/articles/2018/01/01/missing-\$15Billionhaunts-minister 
Fearon, J.D. 1999. What is Identity (As we Now Use the Word)? Stanford: Stanford University.

Gono, G. 2009. Monetary Policy Statement.

http://www.rbz.co.zw/assets/mpsjanuary2010.pdf.

Hakim, C. 1982. Secondary Analysis in Social Research: A Guide to Data Sources and Method Examples. London, UK: George Allen \& Uwin.

Herald, 24 June 2019. https://www.herald.co.zw

Herald, 28 April 2016. https://www.herald.co.zw/missing-\$15billion-lootersface-probe.

Herlihy, J.M., A. Shaikh, A. Mazimba, N. Gagne, C. Grogan, C. Mpamba, B.

Sooli, G. Simamvwa, C. Mabeta, P. Shankoti, L. Messersmith, K. Semrau, \& D.H. Hamer 2013. Local Perceptions, Cultural Beliefs and Practices that Shape Umbilical Cord Care: A Qualitative Study in Southern Province, Zambia. PLoS One November 7,8,11: e79191.

https://doi.org/10.1371/journal.pone.0079191

PMID: 24244447 PMCID: PMC3820671

International Organization for Migration (IOM) 1997. Trafficking in Migrants. Quarterly Bulletin 13,March.

International Organization for Migration (IOM) 2009. Establishing a National Migration Management and Diaspora Policy: Lessons Learned from the Zimbabwe Experience.

James, C. \& S. Atler 2003. Trafficking of Young Women. In Highly Affected, Rarely Considered: The International Youth Parliament Commission's Report on the Impacts of Globalisation on Young People. Sydney: Oxfam International Youth Parliament.

Kanyenze, G., T. Kondo, P. Chitambara \& J. Martens 2014. Beyond the Enclave: Towards a Pro-Poor and Inclusive Development Strategy for Zimbabwe. Harare: Weaver Press.

Kiwanuka, M. T. Monson 2009. Zimbabwean Migration into Southern Africa: New Trends and Responses. Johannesburg: Forced Migration Studies Programme, Wits University.

Leary, M.R. \& J.P. Tangney 2012. Handbook of Self and Identity. New York, London: The Guilford Press.

Makina, D. 2008. A Profile of Zimbabwean Migrants in Johannesburg. In Migration from Zimbabwe: Numbers, Needs, and Policy Options. Johannesburg: Centre for Development and Enterprise.

Makombe, R. 2014. Cultural Nationalism. In Mashingaidze Gono's, a fine 
madness. Tydskrif vir Letterkunde 51,2,September: 82 - 93.

http://dx.org/10.4314/Tvl.v51i2.7

Maposa, R.S., D. Gamira \& J. Hlongwane 2010. Land as a Sacrificial Lamb:

A Critical Reflection on the Effects of Colonial and Post-independent Land Management Policies in Zimbabwe. Journal of Sustainable Development in Africa 12,6.

Masunungure, E.V. 2014. The Changing Role of Civil Society in Zimbabwe's Democratic Process: 2014 and Beyond.

https://library.fes.de/pdf-files/bueros/simbabwe/13718.pdf

Masvotore, P. 2019. Youths without Pasts, Presents and Futures: African Youths and the Resilient (Neo) Colonial Dispossession. In Nhemachena, A. \& T.V. Warikandwa (eds.): From African Peer Review Mechanisms to African Queer Review Mechanisms? Robert Gabriel Mugabe, Empire and the Decolonisation of African Orifices. Bamenda: Langaa RPCIG. JSTOR www.jstor.org/stable/j.ctvhn0cqp

Moyo, S. 2000. The Political Economy of Land Acquisition and Redistribution in Zimbabwe, 1990-1999. Journal of Southern African Studies 26,1. https://doi.org/10.1080/030570700108351

Muzondidya, J. 2008. Survival Strategies among Zimbabwean Migrants in South Africa. International Conference on the Political Economies of Displacement in Zimbabwe, Wits University, 9 - 11 June 2008.

Muzondidya, J. 2010. Migration, Citizenship and Identity among Zimbabweans in South Africa. In McGregor, J. \& R. Primorac (eds.): Displacement and Survival: Zimbabwe's Diasporas Identities and Connections. London: Berghahn Publishers.

Ndlovu-Gatsheni, S.J. 2009. Do Zimbabweans Exist? Trajectories of Nationalism: National Identity Formation and Crisis in a Postcolonial State. Oxford, Bern, Berlin, Frankfurt, New York: Africa in Development. https://doi.org/10.3726/978-3-0353-0253-0

Newsday 16 March 2016. Chiadzwa 15 Billion Diamond Plunder.

https://www.newsday.co.zw/2016/03/chiadzwa-15billion-diamondplunder

Ngugi wa Thiong'o 1993. Moving the Centre: The Struggle for Cultural Freedoms. London: James Currey.

Nhemachena, A. 2017. Hearing the Footfalls of Humanoid Robots: Technoscience, (Un-)Employment and the Future of 'Development' in Twentyfirst Century Africa. In Mawere, M. (ed.): Underdevelopment, 
Development and the Future of Africa. Bamenda: Langaa RPCIG. https://doi.org/10.2307/j.ctvk3gm22.4

Nhemachena, A. 2016. Social Support and the Violence of Individualistic Ontologies: Insights from Namibian Male and Female Youths, in Mawere, M. et al. (eds.): Myths of Peace and Democracy? Towards Building Pillars of Hope, Unity \& Transformation in Africa. Bamenda: Langaa RPCIG. https://doi.org/10.2307/j.ctvk3gm8z.6

Nyamnjoh, F.B. 2012. 'Potted Plants in Greenhouses': A Critical Reflection on the Resilience of Colonial Education in Africa. Journal of Asian \& African Studies 47,2: 129 - 154.

https://doi.org/10.1177/0021909611417240

Panganayi, M. 2014. Reforms in Zimbabwe 1990-2013. In Moyo, T., T.

Chemwaita, T. Murairwa \& M. Panganayi (eds.): National and Strategic Studies Volume One: Diploma in Education Open and Distance Learning. Harare: UZ Department of Teacher Education.

Raftopoulos, B. \& A. Mlambo (eds.): 2009. Becoming Zimbabwe. A History from the Pre-colonial Period to 2008. Harare: Weaver Press.

https://doi.org/10.2307/j.ctvk3gmpr

Ranger, T.O. 1967. The Role of the Ndebele and Shona Religious Authorities in the Rebellion of 1896 and 1897. Zambezian Past: Studies in Central African History. Manchester: Manchester University Press.

Utete, C.M. 2003. Report on the Presidential Land Review Committee. Harare: Government Printers.

Rukundwa, L. \& A.G. van Aarde 2007. The Formation of Postcolonial Theory. HTS 63,3: 1171 - 1194. https://doi.org/10.4102/hts.v63i3.237

Tepeciklioglu, E.E. 2012. The Development of Postcolonial Theory. Bremen: Yasar University.

Tevera, D. J. Crush 2003. The New Brain Drain from Zimbabwe. Migration Policy Series No. 29, SAMP.

The Bible Revised Standard Version 1952. Westlea: Bible Society.

Ukeje, C.U. \& A. Iwilade 2012. A Farewell of Innocence? African Youths and Violence in the Twenty First Century'. International Journal of Conflict and Violence 6,2: 339 - 351.

United Nations (UN) 2005. Report and Recommendations of the Meeting: Outcome Document from the Consultative Meeting on the 10-year Review of the World Programme of Action for Youth. Coimbra, Portugal, 31 January to 3 February. 
Warikandwa, T.V., A. Nhemachena \& N. Mpofu 2017. Double Victimisation? Law, Decoloniality and Research Ethics in Post-Colonial Africa. In Africology: The Journal of Pan African Studies 10,2.

Government of Zimbabwe 2013. Constitution of Zimbabwe Amendment (No 20) Act 2013. Harare: Fidelity Printers Refiners.

Zinyama, L. 1990. International Migration to and from Zimbabwe and the Influence of Political Changes on Population Movements, 1965 - 1987. International Migration Review 24,4: 748 - 767. https://doi.org/10.1177/019791839002400405

\author{
Peter Masvotore \\ Lecturer \\ Theology Department \\ United Theological College \\ Harare \\ masvotorep@gmail.com
}

